\title{
CONTRIBUȚII LA CUNOASTTEREA FAUNEI DE COLEOPTERE DIN LIVADA DE MERI DIN ZONA DE NORD A REPUBLICII MOLDOVA
}

\begin{abstract}
Baban Elena, Bacal Svetlana, Calestru Livia
Institutul de Zoologie, Chișinău, Republica Moldova; baban.elenav@gmail.com
\end{abstract}

https://doi.org/10.53937/9789975315975.29

În prezent, atât Republica Moldova cât și majoritatea statelor europene, pun accentul pe obținerea produselor ecologice, care să nu poluieze mediul înconjurător și să nu afecteze nici sănătatea consumatorului. Practica agricolă lipsită de produsele chimice de sinteză a permis restabilirea ecosistemelor agricole și în primul rând restabilirea faunei de nevertebrate.

Pentru Republica Moldova, merele sunt unele dintre cele mai consumate fructe, care au și cea mai lungă perioadă de păstrare. Acestea au un rol foarte important în alimentaţia sănătoasă, fiind pline de antioxidanţi și vitamine benefice pentru organism.

Alături de importanța economică și necesitatea sporirii producției este absolut necesară și cunoașterea stării ecologice a ecosistemelor antropizate. Cerecetarea faunei de coleoptere din agroecosisteme permite de a cunoaște starea ecosistemului, idenificând posibile focare de dăunători și potențialii agenți de biocontrol. Pentru a cunoaște fauna de coleoptere din livada de meri s-a realizat un studiu comparativ în anii 2008 și 2010, în perioada de vegetație.

Cercetările știinţifice au fost efectuate în perioada de vegetație a anilor 2008 și 2010, în livada de meri, din localitatea Brânzeni, raionul Edineţ. Colectarea materialului entomologic s-a realizat prin intermediul a câte 10 capcane de sol tip Barber, în fiecare an de cercetare, în decursul întregii perioade de vegetaţie. În total au fost montate câte 70 de capcane Barber. În calitate de lichid fixator-conservant servind soluţia concentrată de $\mathrm{NaCl}$, utilizându-se vase cu un volum de $700 \mathrm{ml}$ și diametrul de $75 \mathrm{~mm}$.

În rezultatul investigaţiilor efectuate prin metoda Barber, au fost obţinute 
date noi privind componenţa de specii, abundenţa și dominanţa coleopterelor din livada de meri. În total au fost colectate 215 exemplare de coleoptere ce aparțin la 41 de specii, 22 de genuri și 6 familii.

Din familia Carabidae au fost colectate 39 de exemplare ce aparțin la 21 de specii și 11 genuri. Urmează familiile Scarabaeidae și Silphidae cu câte 8 specii fiecare. Din familia Scarabaeidae au fost colectate 75 de exemplare, ce aparțin la 4 genuri, iar din familia Silphidae - 80 exemplare, din 3 genuri. Un număr mai mic de exemplare a fost înregistrat în cadrul familiei Tenebrionidae (19 exemplare), fiind reprezentată prin 2 specii și 2 genuri. Din familiile Lucanidae și Cerambycidae a fost înregistrat doar câte un singur exemplar.

În anul 2008, din livada de meri au fost colectate în total 112 exemplare, ce aparțin la 29 de specii, 19 genuri și 4 familii. Cele mai multe specii și genuri le-au avut familiile: Carabidae - 25 exemplare, din 17 specii și 10 genuri, urmată de familiile Silphidae - 53 exemplare, 5 specii, 3 genuri, Scarabaeidae - 21 exemplare, 5 specii, 4 genuri și Tenebrionidae - 13 exemplare, 2 specii, 2 genuri.

În anul 2010, sau colectat în total 103 exemplare, ce aparțin la 21 de specii, 13 genuri și 6 familii. Cel mai mare număr de exemplare a fost colectat din familiile Scarabaeidae și Silphide, 54 exemplare și respectiv 27. Din familia Carabidae au fost înregistrate 14 exemplare, 6 exemplare din familia Tenebrionidae. Doar câte un singur exemplar a fost colectat din familiile Lucanidae și Cerambycidae. În ceea ce privește numărul de specii dominante, prima se clasează familia Carabidae - cu 7 specii din 6 genuri, urmată de familiile Scarabaeidae - 6 specii, 2 genuri, Silphidae - 5 specii, 2 genuri. Celelalte 3 familii (Tenebrionidae, Lucanidae și Cerambycidae) sau evidențiat prin câte o singură specie fiecare.

Din totalul de 41 de specii înregistrate în livada de meri 9 specii au fost înregistrate în ambii ani de cercetare.

În fauna coleopterelor colectate prin metoda Barber, din livada de meri din zona de nord a republicii, au fost evidenţiate 5 grupe trofice: fitofagi, zoofagi, necrofagi, coprofagi și xilofagi. Din totalul speciilor identificate, după numărul de specii predomină grupa fitofagă (16 specii), fiind urmată cu un număr apro- 
ximativ egal de către grupele zoofagă ( 9 specii), necrofagă ( 8 specii) și coprofagă (7 specii) și doar o singură specie xilogagă. Cât privește numărul de indivizi pe specii, dominante s-au dovedit a fi grupele: necrofagă cu 80 de indivizi și coprofagă cu 72, ceea ce prezintă un raport de 1/10 (specii/indivizi), urmată de grupa fitofagă cu 47 indivizi, adică 1/3. Zoofagii înregistrează un raport de aproape 1/2 (Fig. 1.).

Specia xilofagă semnalată în livada de meri, a fost Lucanus cervus, care este o specie cu răspândire europeană, caracteristică pentru pădurile cu esențe foioase. Specia a apărut în livadă cel mai probabil din pădurea de carpen cu stejar și frasin din apropiere. Este o specie vulnerabilă inclusă în a 3 ediție a Cărții Roșii.

Speciile de coleoptere colectate din zona de nord a republicii, conform arealului de distribuție se atribuie la 9 elemente zoogeografice cu predominarea celor trans-palearctice (14 specii), urmate de cele europene (10 specii) și euro-caucaziene (6 specii), care constituie peste $70 \%$ dintre speciile colectate. Cu un număr mai mic de specii se prezintă elementele vest-palearctice (4 specii), euro-siberiene (2), holarctice (2) și câte o specie din grupele mediteraneană, pontică și palearctică.

Studiile au fost realizate în cadrul proiectului instituțional fundamental 15.817.02.12F. 